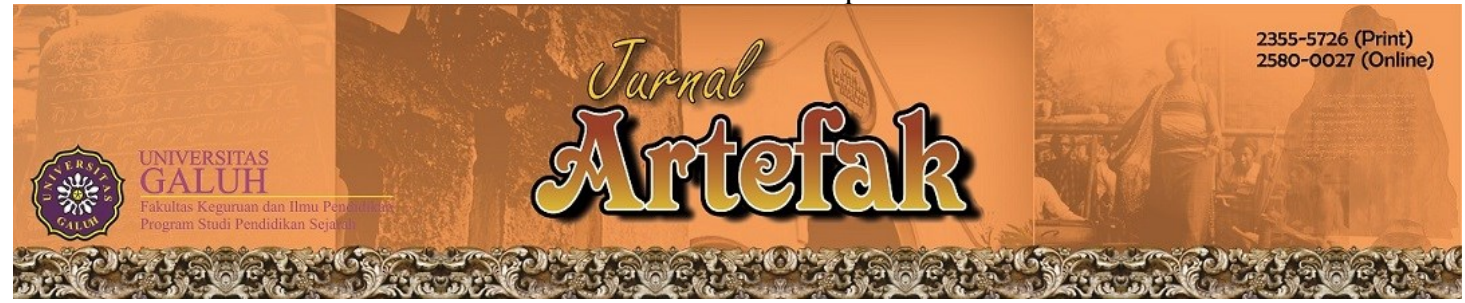

https://jurnal.unigal.ac.id/index.php/artefak/article/view/6713

\title{
PENINGKATAN APRESIASI SISWA TERHADAP NILAI-NILAI KEARIFAN LOKAL DALAM PEMBELAJARAN SEJARAH DENGAN MEDIA TRADISI SEDEKAH LAUT CILACAP
}

\author{
Sudarto \\ Program Studi Pendidikan Sejarah, FKIP, Universitas Galuh, Indonesia ${ }^{1}$ \\ E-mail: mamassudarto81@gmail.com \\ Sejarah Artikel:Diterima 15 Juli 2021, Disetujui: 27 Agustus 2021, Dipublikasikan: 30 September 2021
}

\begin{abstract}
Abstrak
Penelitian bertujuan meningkatkan apresiasi siswa terhadap nilai-nilai kearifan lokal dengan dampak pengiringnya peningkatan hasil belajar sejarah. Model pembelajaran yang digunakan adalah model kooperatif tipe group investigation berbantu media tradisi sedekah laut Cilacap. Penelitian ini merupakan Classroom Action Research dengan tiga siklus tindakan. Prosedur kerja pelaksanaan tindakan melalui enam langkah GI dengan lima kegiatan yakni: 1) Apresiasi (langkah 1 GI); (2) eksplorasi (langkah 2 dan 3 GI); (3) elaborasi (langkah 4 dan 5 GI); (4) konfirmasi (langkah 6 GI); dan (5) penutup. Adapun teknik pengumpulan data yaitu; observasi, dokumentasi, wawancara, test, dan angket. Analisis data menggunakan deskriptif kuantitatif dan kualitatif. Penelitian dilaksanakan di SMA Islam Darul Ulum Cipari pada kelas X.IPS Tahun Ajaran 2020/2021. Hasil penelitian menunjukkan: (1) Penerapan model kooperatif tipe GI dengan media tradisi sedekah laut efektif meningkatkan hasil belajar sejarah dari Nilai rata-rata 6,00 dengan ketuntasan hasil belajar 40,63\% presentasi hasil prestasi $75,00 \%$ pada siklus I, mengalami peningkatan menjadi 7,08 dengan ketuntasan belajar $78,13 \%$ presentasi hasil prestasi $83,27 \%$ pada siklus II, dan meningkat kembali menjadi 7,88 dengan ketuntasan $93,75 \%$ presentasi hasil belajar 87,50\%; (2) Penerapan pembelajaran ini meningkatkan apresiasi siswa, terlihat dengan presentase peningkatan skala sikap $84,37 \%$ (siklus I), menjadi 93,75\% (siklus II), pada siklus III sebesar 96,88\%.
\end{abstract}

Kata kunci: Nilai- nilai Kearifan Lokal, Tradisi sedekah Laut, Kooperatif Tipe Group Investigation

\begin{abstract}
The research aims to increase students' appreciation of the values of local wisdom with the accompanying impact of increasing historical learning outcomes. The learning model used is a cooperative model of group investigation type assisted by the Cilacap sea alms tradition media. This research is a Classroom Action Research with three cycles of action. The work procedure for implementing the action goes through six GI steps with five activities, namely: 1) Appreciation (step 1 GI); (2) exploration (GI steps 2 and 3); (3) elaboration (steps 4 and 5 GI); (4) confirmation (step 6 GI); and (5) closing. The data collection techniques are; observation, documentation, interviews, tests, and questionnaires. Data analysis used quantitative and qualitative descriptive. The research was carried out at SMA Islam Darul Ulum Cipari in class X.IPS the Academic Year 2020/2021. The results showed: (1) The application of the GI type cooperative model with the sea alms tradition media effectively increased history learning outcomes from an average value of 6.00 with complete learning outcomes $40.63 \%$ presentation of achievement results $75.00 \%$ in the first cycle, experiencing an increase to 7.08 with $78.13 \%$ learning completeness presentation of $83.27 \%$ achievement results in the second cycle, and increasing again to 7.88 with $93.75 \%$ learning completeness presentation of $87.50 \%$ learning outcomes; (2) The application of this learning increases student appreciation, as seen by the percentage increase in the attitude scale from $84.37 \%$ (cycle I), to $93.75 \%$ (cycle II), in the third cycle it is $96.88 \%$.
\end{abstract}

Keywords: Local Wisdom Values, Sea Alms Tradition, Cooperative Types of Group Investigation 


\section{PENDAHULUAN}

Penelitian ini dilaksanakan berlandaskan pada anggapan bahwa pelajaran sejarah sebagai mata pelajaran membosankan, kurang menarik dan kurang disukai oleh peserta didik. Selain itu figur pendidik yang kurang professional dalam mengajarkan sejarah dan belum menggunakan fasilitas mengajar sesuai standar kurikulum, ditambah lagi pendidik sering memberikan soal dan pertanyaan sulit, jam pelajaran sejarah terkadang ditempatkan pada jam terakhir, kurangnya media pembelajaran sejarah yang dapat memotivasi siswa untuk memahami materi juga ikut mempengaruhi tingkat kebosanan peserta didik apalagi sekolahsekolah yang berada jauh dari pusat kota yang umumnya masih minimnya fasilitas sarana pendukung dalam pembelajaran sejarah.

Perubahan cara mengajar pun telah dilakukan dengan berbagai upaya namun semua itu tidak begitu banyak menyentuh minat dari peserta didik. Sebagai contoh pembelajaran sejarah dengan karya wisata atau studi wisata telah pula digalakan namun kenyataannya peserta didik belum bisa memaknai dan mengapresiasi pembelajaran sejarah ditambah lagi dengan tugas pembuatan makalah hasil karya wisata umumnya mereka merasakan semua itu sebagai suatu beban.

Widja (1989: 9-10), menyatakan sejarah tidak akan berfungsi bagi proses pendidikan yang menjurus kearah penumbuhan dan pengembangan karakter bangsa apabila nilai-nilai sejarah tersebut belum terwujud dalam pola-pola perilaku nyata. Untuk sampai taraf wujud perilaku ini, perlu pertama-tama ditumbuhkan apa yang disebut kesadaran sejarah.

Mengembalikan rasa keberminatan peserta didik terhadap mata pelajaran sejarah dan mengubah persepsi yang menghakimi pelajaran sebagai pelajaran menjenuhkan yaitu mengupayakan penciptaan pola pembelajaran sejarah yang menarik dan dekat dengan situasi/kondisi lingkungannya yaitu memasukkan unsur-unsur sejarah lokal atau tradisi lisan (oral tradition) terutama kaitannya dengan Nilai-nilai Kearifan Lokal Budaya/Tradisi suatu daerah. Di sini pendidik dituntut untuk dapat mengemas pembelajaran sejarah yang menarik dan aktual, memilih metode sajian, gaya belajar dan diperlukan pengorganisasian bahan pengajaran yang baik agar dapat menghasilkan internalisasi nilai dalam pembelajaran sejarah yang bermakna.

Tak dapat dipungkiri kemajuan IPTEK telah membawa dampak yang sangat luas, terutama dalam dunia pendidikan. Memudarnya rasa kecintaan terhadap budaya yang berakibat hilangnya nilai-nilai kearifan lokal yang telah lama dijunjung tinggi oleh para leluhur kita, nilai, norma dan tata kelakuan selaku masyarakat jawa kini sudah tidak tampak lagi dalam kehidupan seharihari. Mata pelajaran sejarah merupakan mata pelajaran yang memiliki tujuan mengembangkan perilaku didasarkan nilai dan norma yang mencerminkan karakter diri, masyarakat dan bangsa, mencoba memadukan nilai-nilai kearifan lokal dalam materi pembelajaran yang nantinya siswa dapat mengapresiasikan kembali nilai-nilai yang telah terlupakan. Salah satu bahan yang dapat dijadikan materi pelajaran sejarah adalah tradisi sedekah laut, dipilihnya tradisi ini menjadi bahan ajar dengan landasan: (1) memiliki nilai-nilai kesejarahan/ peristiwa sejarah; 2) nilai pendidikan; 3) nilai moral; 4) nilai religius; 5) nilai ekologi; dan 6) memiliki keterkitan dengan materi terutama pada pokok bahasan tradisi masyarakat Indonesia.

Dimasukanya tradisi sedekah laut yang memiliki nilai-nilai kearifan lokal dalam pembelajaran sejarah bertujuan agar siswa mudah dalam memahami materi pembelajaran dan meningkatkan hasil belajar siswa. Selain itu diharapan siswa mampu mengapresiasikan nilai-nilai kearifan lokal dalam kehidupan sehari-hari. Salah satu cara yang dapat dilakukan di sekolah untuk melestarikan budaya lokal terutama nilai-nilai kearifan lokal adalah dengan mengintegrasikan nilainilai yang terkandung didalam budaya tradisi sedekah laut melalui pembelajaran sejarah. Namun perlu diperhatiakan dalam pengintegrasian itu tentunya harus disesuaikan dengan materi yang akan disampaikan, perkembangan peserta didik, metode dan model yang akan digunakan oleh pendidik serta nilai-nilai apa yang sesuai agar tidak keluar dari tujuan pembelajaran tersebut.

Nilai-nilai kearifan lokal yang ada disekitar sekolah dapat dimanfaatkan sebagai bahan pembelajaran sejarah. Dengan diintegrasikannya nilai-nilai kearifan lokal dalam pembelajaran di sekolah diharapkan peserta didik akan memiliki pemahaman tentang nilai-nilai kearifan budaya lokalnya sendiri dan pemahaman nilai sejarah, sehingga 
pada akhirnya menimbulkan kecintaannya terhadap budayanya sendiri. Melalui integrasi nilai-nilai kearifan lokal ini juga diharapkan siswa mampu menumbuhkan rasa nasionalisme terhadap kebudayaan nasional dan menghargai, menjaga, mengembangkan serta meningkat-kan pelestarian kebudayaan lokalnya.

Hal ini sesuai dengan pendapat Aman (2011:10-11) bahwa untuk mengemas pendidikan sejarah sehingga dapat menghasilkan internalisasi nilai, diperlukan adanya pengorganisasian bahan yang beraneka ragam serta metode sajian yang bervariasi. Disamping itu gaya belajar subjekdidik juga perlu mendapat perhatian, agar tidak kehilangan bingkai moral dan apeksi dari seluruh tujuan pengajaran yang telah ada. Karena tanpa bingkai moral, pengajaran sejarah yang terlalu mengedepankan aspek kognitif tidak akan banyak pengaruhnya dalam rangka memantapkan apa yang sering disebut sebagai jatidiri kepribadian bangsa. Untuk itu para pengajar sejarah ataupun para peminat sejarah harus mempunyai wawasan yang luas dan mendalam tentang hakekat suatu sejarah, sehingga tujuan pendidikan secara substansial dapat tercapai. Dalam kaitan ini, pendidikan sejarah perlu mentransfer nilai-nilai etik dan moral yang mendasari cara berfikir, cara bersikap, dan berprilaku seseorang untuk mewujudkan keharmonisan kehidupan individu, kelompok masyarakat atau bangsa dalam membangun perdamaian, toleransi dan kesediaan menerima perbedaan. Adapun rumusan masalah yang akan diteliti adalah sebagai berikut:

1. Bagaimana perencanaan penerapan model kooperatif tipe group investigation dalam pembelajaran sejarah dengan media tradisi sedekah laut untuk meningkatkan apresiasi siswa terhadap nilai-nilai kearifan lokal.

2. Bagaimana penerapan model kooperatif tipe group investigation dalam pembelajaran sejarah dengan media tradisi sedekah laut untuk meningkatkan prestasi hasil brlajar sejarah siswa.

3. Bagaimana penerapan model kooperatif tipe group investigation dalam pembelajaran sejarah dengan media tradisi sedekah laut untuk meningkat-kan apresiasi siswa terhadap nilai-nilai kearifan lokal.

\section{METODE PENELITIAN}

Metode yang digunakan dalam penelitian ini adalah penelitian tindakan kelas menggunakan model pembelajaran kooperatif tipe group investigation dengan media tradisi sedekah laut. Penelitian ini dilakukan pada kelas X.IPS SMA Islam Darul Ulum Cipari Kabupaten Cilacap, dan berlangsung dengan 3 siklus. Waktu dari perencanaan sampai penulisan laporan hasil penelitian tersebut dilaksanakan pada semester ganjil tahun ajaran 2020/2021. Pelaksanaanya dilakukan dalam 6 kali pertemuan. Peneliti dan guru bekerja sama dalam merencanakan tindakan kelas dan merefleksi hasil tindakan. Pelaksanaan tindakan dilakukan oleh peneliti dan guru mata pelajaran sejarah bertindak sebagai observer atau pengamat selama proses pembelajaran berlangsung. Sesuai dengan prosedur penelitian tindakan kelas ini, maka desain penelitian adalah model siklus dengan pelaksanaannya 3 siklus yaitu siklus I, siklus II dan siklus III. Siklus I terdiri dari perencanaan tindakan, pelaksanaan tindakan, pengamatan dan refleksi. Hasil pengamatan dan refleksi pada siklus I diadakan perbaikan proses pembelajaran pada siklus II begitu seterusnya sampai tercapai indikator yang telah ditetapkan.

Instrument penelitian ini yaitu perangkat pembelajaran yang terdiri dari silabus, RPP, instrumen pengumpulan data terdiri dari; observasi, wawancara, test, angket, dan dokumentasi.

Data yang diperoleh melalui lembar pengamatan, test dan angket siswa kemudian dianalisis. Teknik analisis data yang digunakan adalah statistik deskriptif yang bertujuan untuk mendeskripsikan data tentang aktifitas siswa dan guru selama proses pembelajaran dan data ketuntasan belajar siswa. Analisis data tentang aktivitas guru dan siswa didasarkan dari hasil lembar pengamatan yang berguna untuk mengamati seluruh aktifitas yang dilakukan oleh guru dan siswa selama proses pembelajaran. 


\section{HASIL PENELITIAN DAN PEMBAHASAN}

\section{Perencanaan Penerapan Model Kooperatif Tipe Group Investigation Dalam Pembelajaran Sejarah Dengan Media Tradisi Sedekah Laut Untuk Meningkatkan Apresiasi Siswa Terhadap Nilai-nilai Kearifan Lokal}

Dalam perencanaan penerapan model pembelajaran kooperatif tipe group investigation dengan media tradisi sedekah laut untuk meningkatkan apresiasi siswa terhadap nilai-nilai kearifan lokal perangkat pembelajaran yang dipersiapkan adalah berupa silabus, rencana pelaksanaan pembelajaran (RPP) sesuai dengan langkahlangkah dalam model kooperatif tipe group investigation, media pembelajaran sejarah berupa video ritual tradisi sedekah laut, lembar soal evaluasi, dan angket penilaian sikap apresiasi terhadap nilai-nilai kearifan lokal dan lembar observasi guru.

Untuk menentukan media pembelajaran tidaklah mudah, hal ini memerlukan pemikiran yang matang, disini guru harus dapat memilih bahan materi apa yang akan disampaikan berkaitan kesesuaian karakteristik yang dimiliki siswa sehingga tidak menyimpang dari materi yang disampaikan dengan media tradisi sedekah laut tersebut. Pemilihan media pembelajaran sejarah khususnya pada materi pokok tradisi sejarah masyarakat Indonesia haruslah dapat motivasi siswa untuk belajar, oleh sebab itu, hendaknya guru harus dapat memilih media yang sesuai dengan materi maupun tujuan pembelajaran serta dapat meningkatkan apresiasi siswa terhadap nilai-nilai kearifan lokal dengan indikator pendampingnya adalah peningkatan hasil belajar siswa.

Untuk mewujudkan hal tersebut, seorang guru sebagai pengelola pembelajaran harus mempertimbangkan kesesuaian media pembelajaran yang digunakan dengan materi pelajaran yang disampaikan dan juga sarana dan prasara sekolah. Selain itu guru harus memiliki kemampuan dalam memilih media pembelajaran yang sesuai dengan kebutuhan dan tujuan pembelajaran.

Hal ini sesuai dengan pendapat Sadiman (1996:17-18), dengan menggunakan media pembelajaran secara tepat dan bervariasi dapat diatasi sifat pasif anak. Dalam hal ini media pembelajaran berfungsi untuk: a) menimbulkan kegairahan belajar; b) memungkinkan interaksi yang lebih langsung antara anak didik dengan lingkungan dan kenyataan; dan c) memungkinkan pebelajar sendiri-sendiri menurut kemampuan dan minatnya.

Dipilihnya tradisi sedekah laut sebagai media pembelajaran disebabkan karena dalam tradisi sedekah laut terdapat pesan-pesan esensial yang menunjang pelajaran sejarah terutama pada pokok bahasan tradisi sejarah masyarakat Indonesia. Materi esensial tersebut berkaitan dengan cara masyarakat masa aksara terkait pelestarian nilai-nilai sejarah budaya bangsa, berbagai jenis folklore, nilai, norma, adat istiadat dan tradisi dalam masyarakat yang semuanya merupakan sebuah kearifan lokal.

Hal ini sejalan dengan hasil penelitian Warsito (2001), Adapun alasan upacara sedekah laut dijadikan bahan materi pembelajaran disebabkan pertimbangan pokok yaitu aspek historis, yakni peristiwa sedekah laut masyarakat nelayan Cilacap telah menjadi "Peristiwa Sejarah" karena menurut rekonstruksi ahli sejarah telah terkait pada kejadian lain yang dianggap berarti.

Berkaitan dengan penerapan model pembelajaran tipe group investigation melalui media tradisi sedekah laut, siswa diajak untuk mengembangkan pemikiran dan wawasan tentang nilai-nilai kearifan budaya lokal, selain itu melalui media tradisi sedekah laut mereka diajak untuk menginvestigasi materi pelajaran yang berkaitan dengan tradisi sejarah masyarakat Indonesia. Hal ini sejalan dengan pendapat Sutarno (2008:7-6) pembelajaran sejarah berbasis budaya yaitu belajar dengan budaya, terjadi pada saat budaya diperkenalkan kepada siswa sebagai cara atau metode untuk mempelajari pokok bahasan tertentu. Belajar dengan budaya meliputi pemanfaatan beragam perwujudan budaya. Dalam belajar dengan budaya, budaya dan perwujudannya menjadi media dalam proses belajar, menjadi konteks dari contohcontoh tentang konsep atau prinsip dalam suatu mata pelajaran, serta menjadi konteks penerapan prinsip atau prosedur dalam suatu mata pelajaran; Belajar melalui budaya, merupakan strategi yang memberi-kan kesempatan siswa untuk menunjukkan pencapaian pemahaman atau makna yang diciptakannya dalam suatu mata pelajaran melalui ragam perwujudan budaya; dan Belajar berbudaya, merupakan bentuk mengejawantahkan budaya itu dalam prilaku 
nyata sehari-hari siswa, misalnya, anak dibudayakan untuk selalu menggunakan bahasa krama inggil pada setiap hari sabtu melalui program sabtu budaya.

Tradisi sedekah laut dapat menjadi sebuah proses pendidikan bagi masyarakat selain sebagai atraksi budaya, tradisi sedekah laut juga memiliki nilai-nilai yang membentuk karakter bangsa seperti rasa bersyukur kepada sang pencipta, menghargai leluhur, kerjasama, gotong royong, etos kerja, toleransi, solidaritas, pelestarian lingkungan dan masih banyak pelajaran lain yang dapat diambil dalam tradisi sedekah laut. Sedekah laut juga dapat menjadi sarana enkulturasi, sosialisasi dan inkulturasi.

Penerapan model pembelajaran kooperatif group investigation dengan media tradisi sedekah laut tidak akan berhasil apabila guru tidak memahami dan memiliki wawasan tentang kearifan lokal itu sendiri. Sehingga disini guru dituntut untuk dapat mengembangkan kreatifitas dalam pembelajaran. Namun disini perlu diperhatikan guru harus dapat memilah dan memilih nilai-nilai dan materi apa yang tepat untuk diajarkan pada anak yang memiliki latar belakang dan lingkungan yang berbeda-beda. Sejalan dengan hal tersebut Hamalik (2001:118), mengemukakan ada beberapa syarat menjadi seorang guru yang baik dan professional yaitu: 1) harus memiliki bakat dan keahlian sebagai seorang guru; 2) memiliki kepribadian yang baik dan terintegrasi; 3) memiliki mental yang sehat; 4) berbadan sehat; 5) memiliki pengalaman dan pengetahuan yang luas; 6) guru adalah manusia yang berjiwa pancasila; dan 7) guru adalah seorang warga negara yang baik.

Dengan demikian guru harus benarbenar mampu dan tahu materi apa yang akan diajarkan dan menguasi tekni dan metode apa yang akan digunakan. Guru memiliki peranan penting dalam proses belajar mengajar baik hasil pembelajaran maupun untuk kepribadian siswa. Dengan kata lain seorang guru harus merencanakan proses belajar, dimana terjadi dengan adanya interaksi belajar mengajar. Guru harus dapat memilih bentuk interaksi belajar mengajar yang tepat. Guru bukan memaksa arah perkembangan murid, tetapi membimbing kearah perkembangan murid itu masing-masing. Untuk itu pemahaman tentang murid adalah syarat yang amat penting bagi guru. (Ali, 1987: 98).

\section{Penerapan Model Pembelajaran Kooperatif Tipe Group Investigation Dengan Media Tradisi Sedekah Laut Untuk Meningkatkan Prestasi Belajar Sejarah}

Untuk mengukur prestasi siswa dalam mata pelajaran sejarah, peneliti juga menggunakan test kognitif berupa soal sebanyak 20 nomor dengan jumlah responden sebanyak 32 siswa, pada pra tindakan peneliti menemukan bahwa prestasi belajar sejarah kelas X.IPS hanya sebesar $56,00 \%$ dan ketuntasan belajar sebesar $12,50 \%$ yang didapatkan peneliti dari hasil ulangan harian 1 . Kemudian pada awal tindakan siklus I peneliti melakukan pre-test dan memperoleh hasil sebesar 9,37\%, sedangkan pada akhir tindakan ketika dilakukan post-test diperoleh hasil 40,63\%. Pada saat awal siklus II peneliti juga mengambil data prestasi belajar dengan menggunakan soal sebanyak 20 nomor yang berbeda dari siklus I namun responden yang sama, dari data tersebut diperoleh hasil sebesar $59,38 \%$ dan pada akhir tindakan ketika dilakukan post-test diperoleh hasil sebesar $78,13 \%$.

Dari data tersebut sudah tampak adanya peningkatan hasil prestasi belajar sejarah siswa, demi memperoleh hasil yang maksaimal peneliti melanjutkan penelitian pada siklus selanjutnya. Darai hasil perolehan data pada siklus III, peneliti membagikan soal kepada siswa dengan jumlah soal dan responden yang sama namun soal berbeda dari siklus I dan II namun masih dalam materi yang sama. Dari hasil yang diperoleh pada siklus awal tindakan sebesar $87.50 \%$ dan pada akhir tindakan siklus III sebesar 93,75\%. Melihat hal tersebut antara pra tindakan sampai dengan akhir siklus terlihat adanya peningkatan yang secara terus menerus. Dan ini telah mencapai target dari indikator yang telah ditetapkan. Sehingga peneliti tidak meneruskan tindakan pada siklus berikutnya.

Sedangkan untuk presentasi prestasi belajar yang diperoleh pada saat pra tindakan hanya sebesar $56,00 \%$, pada saat siklus I pretest yang diperoleh $79,24 \%$, sedangkan pada post-test diperoleh $75.00 \%$, selanjutnya pada pre-test siklus II diperoleh $79,04 \%$ dan pada post-test diperoleh $83.27 \%$, kemudian pada saat pre-test siklus III diperoleh $89,65 \%$, dan pada post-test diperoleh $87,50 \%$. Hal ini menunjukan adanya peningkatan ketuntasan hasil belajar, sehingga peneliti menghentikan penelitian. 
Hal ini sesuai dengan hasil penelitian yang dilakukan Lestari (2013), bahwa pemanfaatan media pembelajaran secara optimal dapat mempertinggi kulitas proses belajar mengajar yang pada gilirannya dapat meningkatkan prestasi belajar siswa.

Berdasarkan hasil pengamatan pada siklus I, dapat disimpulkan bahwa dalam pelaksanaan penerapan model pembelajaran group investigation melalui media tradisi sedekah laut ada beberapa hal yang masih kurang diantaranya sebagian siswa masih kurang termotivasi dalam diskusi kelompok, pemanfaatan waktu belum efisien sehingga mempengaruhi pada waktu jam pelajaran yang tersedia dikarenakan siswa masih banyak yang ribut, siswa masih enggan mengajukan pertanyaan, penampilan hasil diskusi kurang maksimal, masih ada anggota kelompok yang ramai sendiri, mengajak ngobrol teman lainnya, mainan HP, merasa kurang nyaman dengan anggota lainnya, cenderung memilihmilih teman dalam kelompok, kurang bersemangat dalam kelompok, ketekunan dan kesungguhan dalam mengerjakan tugas masih rendah dan ketika ada teman yang mengemukakan pendapat malah menyoraki. Hal ini dimungkinkan kurang aktifnya siswa disebabkan karena masih perlu beradaptasi dengan penggunaan model group investigation dan beradaptasi dengan anggota kelompoknya, selain itu, terdapat faktor internal dari diri siswa dimana siswa kurang nyaman dengan teman satu kelompok sehingga malas untuk berdiskusi. Hal ini menunjukan bahwa nilai-nilai kerjasama belum mampu mereka serap, selain itu mereka belum menghargai teman lainnya sehingga mereka tindak menurut egonya masingmasing. Disini dapat disimpulkan bahwa nilainilai kearifan lokal belum dapat mereka laksanakan dengan baik.

Selanjutnya pada siklus II, disini sudah mulai tampak kerjasama yang baik antara anggota kelompok, mereka sudah dapat menghargai pendapat orang lain, terlihat ketika ada yang mengemukakan pendapat mereka menanggapinya dan saling memadukan pendapat-pendapat tersebut untuk dapat menjadi sebuah keputusan dalam mengungkap permasalahan. Mereka telah sopan dalam mengungkapkan idea atau pendapat, saling bekerjasama satu dengan yang lainnya sehingga waktu yang diperlukan tidak terbuang. Pemanfaatan waktu seefisien dan seefektif mungkin terilihat dari cara mereka menyelesaikan tugas tepat waktu. Dari sini terlihat bahwa mereka telah menghargai waktu yang ada, karena waktu sangatlah berharga, didalam ajaran Islam sendiri sebagai seorang muslim dilarang untuk menyia-yiakan waktu, sehingga dengan demikian mereka dapat dikatakan telah memahami nilai kearifan buadaya lokal. Begitupula pada tindakan siklus III, mereka berupaya seminimal mungkin agar waktu yang diberikan dapat dioptimalkan sehingga interaksi dalam diskusi dapat berjalan dan berlangsung dengan baik.

Dalam hal penyajian hasil karya, siswa dituntut untuk berani mengungkapkan gagasan yang dimiliki dan menyelesaikan maslah yang dihadapinya. Selain itu mereka juga dituntut untuk dapat mengembangakan pengetahuan dan sikap solidaritas mereka menghargai dan menjunjung tinggi nilai-nilai musyawarah untuk mencapai satu kata mufakat. Berdasarkan hasil pengamatan, peran guru dalam memberikan kesempatan kepada siswa untuk mengungkapkan gagasannya sudah dilakukan. Pada siklus I hanya ada beberapa siswa yang berani untuk menyampaikan ide dan gagasannya dalam mempresentasikan hasil kerja kelompoknya, siswa masih ada yang malu-malu untuk mempresentasikan hasil investigasinya didepan kelas, selain itu siswa banyak yang pasif dan tidak mampu untuk menyampaikan ide ketika pertanyaan dilemparkan oleh guru sebagai mediator dalam diskusi.

Sedangkan dalam tindakan siklus II dan III, siswa sudah banyak yang mampu menyampaikan ide dan gagasan yang dimilikinya dan menyampaikan informasi dari hasil analisis mereka dan pengetahuan mereka yang berasal dari latar belakang lingkungannya masing-masing, sehingga dalam diskusi ini suasana bertambah ramai dan hidup. Siswa yang tadinya hanya diam terpacu untuk dapat meng-ungkapkan pendapat atau ide dan gagasan yang dimilikinya. Diskusi berlangsung dengan arahan dan panduan dari peneliti.

Berdasarkan hasil penelitian yang telah diuraikan sebelumnya, diketahui bahwa apresiasi terhadap nilai-nilai kearifan lokal siswa SMA Islam Darul Ulum Cipari khususnya kelas X.IPS mengalami peningkatan setelah terapkan model pembelajaran kooperatif tipe group investigation.

Hal ini didasarkan pada data yang diperoleh dari hasil test prestasi dan angket 
skala sikap apresiasi terhadap nilai-nilai kearifan lokal pada saat tindakan baik pada awal tindakan siklus I, II dan III maupun pada akhir tindakan pada Siklus I, II dan III. Tercapainya keberhasilan tersebut tidak terlepas dari peran peneliti dalam proses pembelajaran, pembimbingan, kesesuaian antara tindakan yang ditempuh oleh peneliti dengan rencana tindakan yang telah dipersiapkan peneliti dalam RPP, serta peran serata dari siswa kelas X.IPS pada SMA Islam Darul Ulum Cipari yang berkerjasama selama proses pembelajaran sehingga pembelajaran yang berlangsung dapat berjalan dengan baik. Menurut Slameto (2003), bahwa peran dan fungsi guru sangat menentuakan serta mempunyai pengaruh sangat besar terhadap peningkatan hasil belajar dan mampu mendorong siswa untuk senantiasa belajar dalam berbagai kesempatan sumber dan media.

Secara umum dapat disimpulkan bahwa pembelajaran sejarah melalui penerapan model pembelajaran kooperatif tipe group investigation dengan media tradisi sedekah laut untuk meningkatkan apresiasi terhadap nilai-nilai kearifan lokal pada materi pokok tradisi sejarah masyarakat Indonesia dapat meningkatan apresiasi siswa terhadap nilainilai kebudayaan lokal ditunjang dengan peningkatan prestasi hasil belajar sejarah kelas X.IPS pada SMA Islam Darul Ulum Cipari. Kondisi peserta didik sangat berpengaruh pada hasil belajar yang akan dicapai, misalnya, keadaan fisik sakit, minat, kesiapan, serta kondisi perasaan pada saat peserta didik menerima pembelajaran sangatlah berpengaruh. Selain itu kualitas proses pembelajaran yang dilaksanakan oleh pengajar juga sangat berpengaruh terhadap hasil pencapaian pembelajaran.

\section{Penerapan Model Kooperatif Tipe Group Investigation Dengan Media Tradisi Sedekah Laut Untuk Meningkatkan Apresiasi siswa terhadap Nilai-nilai Kearifan Budaya Lokal}

Pelaksanaan tindakan kelas yang dilakukan peneliti adalah dengan mendapatkan data hasil angket skala sikap apresiasi terhadap nilai-nilai kearifan lokal yang diambil pada saat pra tindakan yang dilakukan oleh peneliti dengan menyebarkan angket berjumlah 30 item untuk dikerjakan sesuai dengan pendapat masing-masing siswa. Jumlah responden adalah sebanyak 32 siswa, waktu yang digunakan adalah 30 menit dengan hasil $68,75 \%$, sedangkan pada akhir siklus I peneliti juga mengedarkan angket skala sikap dengan jumlah item yang sama dan responden yang sama dan dipadaptkan hasil $84,38 \%$, hal ini menunjukkan adanya peningkatan terhadap nilai-nilai kearifan lokal pada saat pra tindakan ke tindakan pada siklus I dengan peningkatan sebesar $15.63 \%$, akan tetapi belum memenuhi target sehingga peneliti mengedarkan angket skala sikap pada akhir pelaksanaan tindakan siklus II dengan jumalah item dan responden yang sama seperti yang telah dilakukan pada siklus I, dalam siklus II didapatkan hasil 93,75\%, dengan peningkatan 9,37\%. Pada akhir tindakan siklus III peneliti menyebarkan angket dengan jumlah item dan responden yang sama dan didapatkan hasil 96,87\% dengan peningkatan sebesar $3,12 \%$, dengan demikian penelitian sudah dianggap memenuhi target yang diharapkan sehingga penelitian kemudian dihentikan. Dari data hasil angket skala sikap apresiasi terhadap nilai-nilai kearifan lokal dari pra tindakan hingga akhir siklus menunjukkan adanya peningkatan yang sangat signifikan terhadap apresiasi nilai-nilai kearifan budaya lokal.

Hal ini sesuai dengan penelitian Ruyadi (2010), dengan model pendidikan karakter berbasis kearifan lokal membawa dampak positif terhadap siswa, sekolah dan masyarakat yang memiliki pola pendidikan efektif dalam mewariskan nilai-nilai budaya dan tradisi kepada generasi berikutnya. Dengan memasukan nilai-nilai kearifan buadaya lokal dalam pengajaran sejarah diharapkan nantinya pembelajaran sejarah dapat lebih fungsional dan terintegrasi dengan berbagai bidang keilmuan lainnya, maka terdapat berbagai bidang yang seyogyanya mendapat perhatian antara lain materi pelajaran sejarah harus mampu mengembangkan kecakapan sosial berupa integritas dan jati diri siswa menyentuh rasa kedaerahan atau lokalitas daerah tertentu dimana peserta didik berada, sehingga terbentuk karakter peserta didik yang memiliki sikap bangga, cintah tanah air, rasa kebersamaan dalam peradaban, toleransi, empati, dan sikap-sikap positif lain yang berharga baik bagi dirinya, masyarakat, maupun bangsa dan negaranya.

Penerapan model pemebelajaran tipe group investigation dalam pembelajaran sejarah melalui media tradisi sedekah laut 
mampu meningkatkan apresiasi siswa terhadap nilai-nilai kearifan budaya lokal dilihat dari hasil angket skala siskap yang semakin mengalami peningkatan dari pra tindakan hingga pada akhir pelaksanaan tindakan siklus III.

Dengan demikian dapat di tarik kesimpulan bahwa tradisi sedekah laut dapat dijadikan materi pembelajaran sejarah khususnya pada materi pembelajaran tradisi sejarah masyarakat di Indonesia. Terutama tradisi lisan yang membahas tentang sejarah dan cara masyarakat mewariskan masa lalunya selain itu juga berkenaan dengan materi folklore, mitologi, dongeng dan legenda diberbagai daerah di Indonesia dan nilai, norma dan tradisi yang diwariskan di dalam sejarah lisan di Indonesia.

Dimasukanya tradisi sedekah laut dalam pembelajaran sejarah bertujuan agar siswa mudah memahami materi pembelajaran dan meningkatkan hasil belajar siswa. Selain itu diharapan siswa mampu mengapresiasikan nilai-nilai kearifan lokal dalam kehidupan sehari-hari. Sejalan dengan hal tersebut Susanti. (2011:9-10) mengemukakan bahwa pendidikan berbasis kearifan lokal dapat digunakan sebagai media melestarikan potensi masing-masing daerah. Kearifan lokal harus dikembangkan dari potensi daerah. Potensi daerah merupakan sumber daya spesifik yang dimiliki suatu daerah tertentu. Guru yang bijaksana harus menyelipkan nilai-nilai kearifan lokal mereka dalam proses pembelajaran.

Pendidikan berbasis kearifan lokal tentu akan berhasil apabila guru memahami wawasan kearifan lokal itu sendiri. Guru yang kurang memahami makna kearifan lokal, cenderung kurang sensitive terhadap kemajemukan budaya setempat. Hambatan lain yang biasanya muncul adalah guru yang mengalami lack of skiil. Akibatnya, mereka kurang mampu menciptakan pembelajaran yang menghargai keberagaman budaya daerah.

\section{KESIMPULAN}

Perencanaan Penerapan model kooperatif tipe group investigation dalam pembelajaran sejarah dengan media tradisi sedekah laut dari hasil lembar observasi sudah dapat dikatakan baik namun perlu adanya peningkatan terutama apresiasi siswa terhadap nilai-nilai kearifan lokal. Hal ini terjadi karena adanya kerjasama antara peneliti dan guru dalam perencanaan dan pelaksanaan penelitian.

Penerapan model kooperatif tipe group investigation dalam pembelajaran sejarah dengan media tradisi sedekah laut dapat meningkatkan hasil prestasi belajar siswa. Hal ini terlihat pada peningkatan hasil belajar di setiap siklusnya.

Penerapan model kooperatif tipe group investigation dalam pembelajaran sejarah dengan media tradisi sedekah laut dapat meningkatkan apresiasi siswa terhadap nilainilai kearifan lokal pada siswa kelas X.IPS SMA Islam Darul Ulum Cipari. Hal ini dapat dilihat dari sikap dan perilaku siswa dalam aktifitas kesehariannya, baik dilingkungan sekolah, keluarga, maupun didalam masyarakat dengan tetap menerapkan nilai, norma, dan adat kebiasaan masyarakat.

\section{DAFTAR PUSTAKA}

Ali, Muhammad, 1987, Guru dalam proses Belajar Mengajar, Bandung: Sinar Baru Algensindo.

Aman, 2011, Model Evaluasi Pembelajaran Sejarah, Yogyakarta: Ombak.

Sadiman, Arief S., 1996, Media Pendidikan, Jakarta: PT Raja Grafindo.

Lestari, Tri Puji, 2013, Penggunaan Media VCD Tradisi Dama Nyili-nyili Masyarakat Tidore Dalam Pembelajaran Sejarah Untuk Meningkatkan Prestasi Belajar dan Kecintaan Siswa Terhadap Tradisi Lokal, Studi Pada Siswa kelas X di SMA Negeri 1 Tidore Kepulauan, Maluku Utara, Tesis: Universitas Sebelas Maret Surakarta.

Hamalik, Oemar. 2001, Perencanaan Pengajaran Berdasarkan Pendekatan Sistem. Bandung: Bumi Aksara.

Ruyadi, Yadi. 2010, Model Pendidikan Karakter Berbasis Kearifan Budaya Lokal (Penelitan terhadap Masyarakat Adat Kampong Benda Kerep Cirebon Provinsi Jawa Barat Untuk Pengembangan Pendidikan Karakter Di Sekolah). Proceedings of The $4^{\text {th }}$ International Conference on Teacher Education,Join Conference UPI \& UPSI Bandung Indonesia, 8-10 November 2010: 579 . 
Slameto, 2003, Belajar Dan Faktor-Faktor Yang Mempengaruhi, Jakarta: Rineka Cipta.

Susanti, Retno, L.R. (2011, 26 s/d 27 Oktober), Membangun Pendidikan Karakter di Sekolah Melalui Kearifan Lokal, in Persidangan Dwitahunan FSUA-PPIK USM Padang. ePrints Sriwijaya University. Diakses 22 Juli 2013.

Sutarno, 2008. Pendidikan Multikultural. Jakarta: Direktorat Jenderal Pendidikan Tinggi Departemen Pendidikan Nasional. Warsito, R., 2001, Upacara Sedekah Laut Masyarakat Nelayan Cilacap Sebagai Perspektif Historis Dalam Kurikulum Muatan Lokal di Sekolah Dasar, Tesis; Uneversitas Negeri Jakarta.

Widja, I Gde, 1989, Dasar-dasar Pengembangan Strategi serta Metode Pengajaran Sejarah: Jakarta: Departemen Pendidikan dan Kebudayaan Direktorat Jenderal Pendidikan Tinggi, Proyek Pengembangan Lembaga Pendidikan Tenaga Kependidikan. 
Jurnal Artefak:

Vol. 8 No. 2 September 2021 [ 203 - 212 ]

Halaman | 212 